2017 Global Fashion Management Conference at Vienna Proceedings: 133 (July 2017) https://doi.org/10.15444/GFMC2017.02.06.02

\title{
UNDERSTANDING THE POTENTIALITIES OF A STRATEGIC ASSOCIATION BETWEEN LUXURY FASHION BRANDS AND FURNITURE DESIGN
}

\author{
Federica Codignola, Università degli Studi di Milano - Bicocca, Italy ${ }^{1)}$
}

\begin{abstract}
Given the recent modest growth of the personal luxury good market and the urge to face difficulties through innovative brands' marketing communication strategies, this paper examines the potentialities of tactical associations between luxury fashion brands and furniture design. Results indicate that there can be positive repercussions deriving from luxury fashion brands and furniture design interconnections. In particular, associations with collectable furniture design may help to define and enhance brands' luxury values whilst providing consumers with innovative and creative luxury brand experiences.

Future expectations in this market show a compound annual rate (CAGR) of 3\% to 4\% through 2020, to just about $€ 280$ billion. This is dramatically slower than the past fast growth experienced from the mid-1990s to the late 2000s. In this scenario, luxury fashion managers and marketers must envision new strategies to succeed and surpass competition. In order to be competitive and successful, luxury brand managers must take into account current market dynamics and find pertinent and substantial solutions.

This paper shifts its attention to the identification of how in such a difficult scenario different cultural industries can meet in order to mutually enhance their circuits of value. Some studies have demonstrated that in order to meet such new global challenges, luxury fashion firms may discover strategic opportunities in art (Codignola, 2016). Given their symbolic connotation and aesthetic value, high-end furniture design items are more and more perceived as art works exchanged in art auctions or fairs, collected and purchased by collectors, exhibited in galleries or museums. At the same time, furniture design goods show some divergences from conventional art works (i.e. functionality, reproducibility, etc.) and some correspondences with fashion goods. By observing the luxury fashion sector, one may then find--for different sets of reasons--more than one interesting intersection with the furniture design sector.

By taking into account the furniture design sector within its specific market features and goods, this paper argues that through furniture design LFBs can develop engaging creative and innovative brands' marketing communication strategies. Compared to art, such strategies would be able to add value and strengthen LFBs' luxury features even in a more effective way.
\end{abstract}

Keywords: creative industries, luxury fashion brands, furniture design, value creation, collaboration, brand's marketing communication strategy

\section{References Available upon Request}

\footnotetext{
1) federica_codignola@yahoo.it
} 